\title{
Binder's syndrome
}

\author{
Upendra Jain, ${ }^{1}$ Gagan Thakur, $^{2}$ Amitabh Kallury ${ }^{1}$ \\ 'Department of Orthodontia, People's College of Dental Sciences and Research Centre, Bhopal, Madhya Pradesh, India; \\ 2Department of Oral and Maxillofacial Surgery, People's College of Dental Sciences and Research Centre, Bhopal, Madhya Pradesh, India
}

Correspondence toDr Gagan Thakur, drgagan05@yahoo.com

\begin{abstract}
Summary
Binder syndrome or maxillonasal dysplasia is an uncommon developmental anomaly affecting primarily the anterior part of the maxilla and nasal complex. The characteristic findings are a failure of development in the premaxillary area with associated deformities of the nasal skeleton and the overlying soft tissues. Affected individuals typically have an unusually flat, underdeveloped midface (midfacial hypoplasia), with an abnormally short nose and flat nasal bridge, underdeveloped upper jaw, relatively protruding lower jaw and/or a 'reverse overbite' (or class III malocclusion). A 16-year-old female reported to clinic with chief complaint of facial deformity, on examination patient had classical feature of maxillonasal dysplasia. A brief review of the condition and the proposed multi-disciplinary treatment plan is discussed.
\end{abstract}

\section{BACKGROUND}

Effects on the facial features are: arhinoid face, intermaxillary hypoplasia (associated with malocclusion), abnormal position of the nasal bones, nasal mucosa atrophy, anterior nasal spine agenesis and (in most cases) a lack of frontal sinuses. Other deformities, as well as mental retardation, are also possible. Due to the clinical appearance, patients require surgical and orthodontic treatment. The main surgery performed in these patients is nose reconstruction with bone or cartilage grafts. Usually patients require more than one surgical procedure due to graft resorbtion and an unsatisfactory appearance. Orthodontic treatment is based on class III treatment (pseudo-mesio-occlusion) and relieving dental crowding. The treatment of malocclusion may require combined orthodontic and surgical treatment. In younger patients, maxillary protraction with rapid palatal expansion could be an adequate approach.

\section{CASE PRESENTATION}

A 16-year-old female reported to the clinic with chief complaint of facial deformity. There was no family history of similar complaint as well medical history was non-contributory. On extra oral examination, the patient had mesoprosopic face with hypoplasia of middle third of the face, a broad, flat nose, horizontal nostrils, a short columella and broad philtrum and a marked groove at the nasolabial junction (figure 1). On profile examination, the patient presented with a concave profile with straight divergence, depressed nose, decreased nasolabial angle and protruded both upper and lower lips; lower third of the face appeared to be normal (figure 2). Intraoral examination reveals class I incisors in relation with Angle's class I molars and canine. There was positive overjet and overbite with lower midline shifted to the left by $1 \mathrm{~mm}$ (figure 3 ). On cephalometric examination, the patient had classical features of skeletal class III malocclusion on account of point A-Nasion-Point B angle of $-4.5^{\circ}$ and Witwatersand appraisal of $-15 \mathrm{~mm}$. This is due to the reduced size (unit maxillary length of $39 \mathrm{~mm}$, normal value $52 \mathrm{~mm}$ ) as well as posterior position of the maxilla
( $\mathrm{N} \perp$ to $\mathrm{Pt} \mathrm{A}-5 \mathrm{~mm}$ ) whereas the size and position of mandible was normal. The maxillo-mandibular deferential was $8 \mathrm{~mm}$ as suggested by position of A-B point on Frankfurt horizontal plane value of $-4 \mathrm{~mm}$ as compare to normal value of $+4 \mathrm{~mm}$. Maxillary incisor were proclined as suggested by one (maxillary central incisor) to relationship of point A to Nasion perpendicular value of $44^{\circ}$ and $17 \mathrm{~mm}$, Sella-Nasion to one value of $121^{\circ}$ (normal value $102^{\circ}$ ), one to palatal plane value $133^{\circ}$ (normal value $110^{\circ}$ ). Position of mandibular incisors was normal. This may be

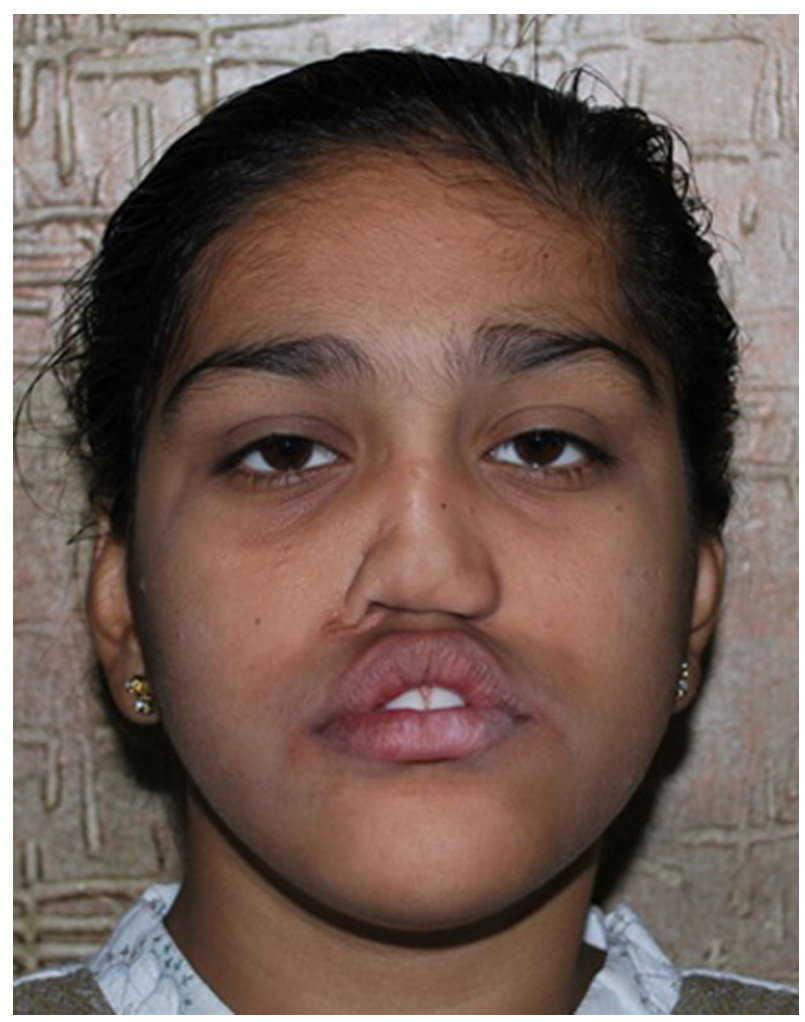

Figure 1 Frontal view. 


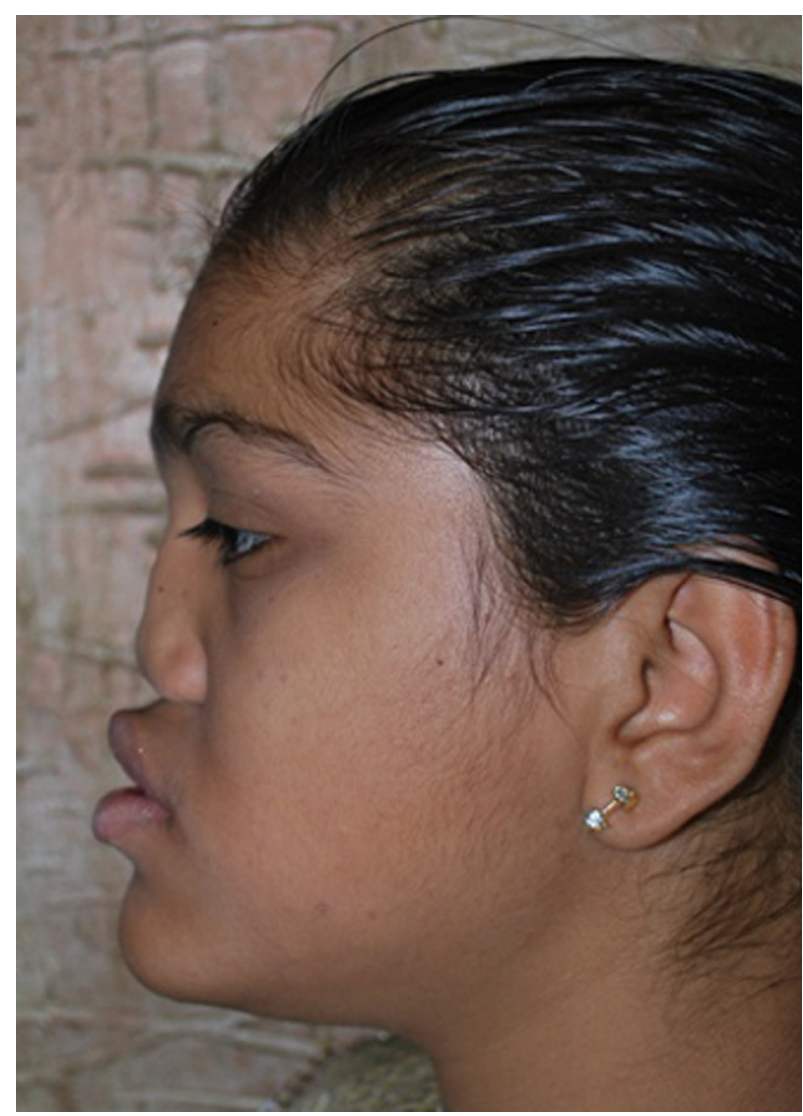

Figure 2 Lateral view.

due to the dentoalveolar compensation of the maxillary deficiency (figures 4 and 5).

\section{INVESTIGATIONS}

- Lateral cephalogram with cephalometric analysis

- Photographs

- Study model

\section{DIFFERENTIAL DIAGNOSIS}

- Warfarin embryopathy

- Down's syndrome

- Apert syndrome

- Stickler syndrome

- Keutel syndrome

- Acrodysostosis.

\section{TREATMENT}

The aims of the treatment were:

- correction of facial deformity

- correction of nasal depression

- to correct proclinaiton of maxillary incisors

- correct the lower centreline

- to obtain a good class I canine and molar occlusion. An interdisciplinary treatment was planed in collaboration with orthodontist and oral and maxillofacial surgeon.

The treatment plan was as follows:

- oral prophylaxis to improve oral hygiene.

- orthodontic treatment to decompensate the malocclusion-extraction of maxillary first bicuspids to retract maxillary incisors, orthodontic micro implants will be

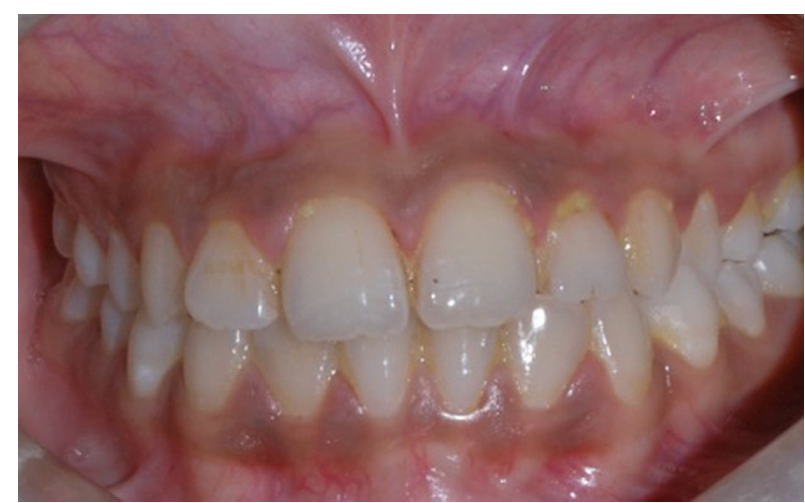

Figure 3 Occlusal relationship.

use to maximise the incisors retraction and to achieve the maximum reverse overjet as possible so as to facilitate the maximum surgical advancement of the maxilla.

- orthognathic surgery (Le Fort I maxillary advancement of $8 \mathrm{~mm}$ ) to correct maxillary deficiency.

- post surgical orthodontic treatment to achieve finishing and detailing for proper intercuspation.

- Rhinoplasty by costal cartilage graft.

\section{DISCUSSION}

Zuckerkandl in 1882 described an anomaly in the anterior nasal floor in which the normal crest that separates the nasal floor from the anterior surface of the maxilla was absent, and instead, a small pit (the fossa prenasalis) constituted the inferior margin of the piriform aperture. ${ }^{1}$ In 1939, Noyes $^{2}$ described a patient with a flat nasal tip sitting on a retruded maxillonasal base, and in 1962, von Binder ${ }^{3}$ described a syndrome consisting of a short nose with a flat bridge, absent frontonasal angle, absent anterior nasal spine, limited nasal mucosa, short columella and acute nasolabial angle, perialar flatness, convex upper lip and a tendency to class III occlusion. Occasionally, there may be hypoplastic frontal sinuses. von Binder postulated that these defects were caused by rhinocephalic dysplasia, which he called 'maxillonasal dysostosis'. Since that time, the condition has been known as maxillonasal dysplasia or Binder syndrome. ${ }^{4}$ Posnick and Tompson ${ }^{5}$ noted that the physical findings of Binder syndrome are the result of hypoplasia (depression) of the anterior nasal floor (fossa prenasalis) and localised symmetric maxillary hypoplasia of the alar rim regions. From the basal view, typical variations from normal include a retracted columella-lip junction; lack of normal triangular flare at the nasal base, a perpendicular alar-cheek junction; convex upper nasal tip with a wide, shallow philtrum; crescent-shaped nostrils without a sill; low-set and flat nasal tip; and stretched and shallow Cupid's bow. ${ }^{6}$ The most striking characteristics of the nose are vertical shortening, lack of tip projection, perialar flattening and an acute nasolabial angle.

Holmstrom found a hereditary connection in 16 per cent of 50 patients with Binder syndrome, and inheritance may be as an autosomal recessive trait with incomplete penetrance. $^{6-8}$

This feature is caused by a disturbance of growth in the prosencephalic induction centre. The process of nose 


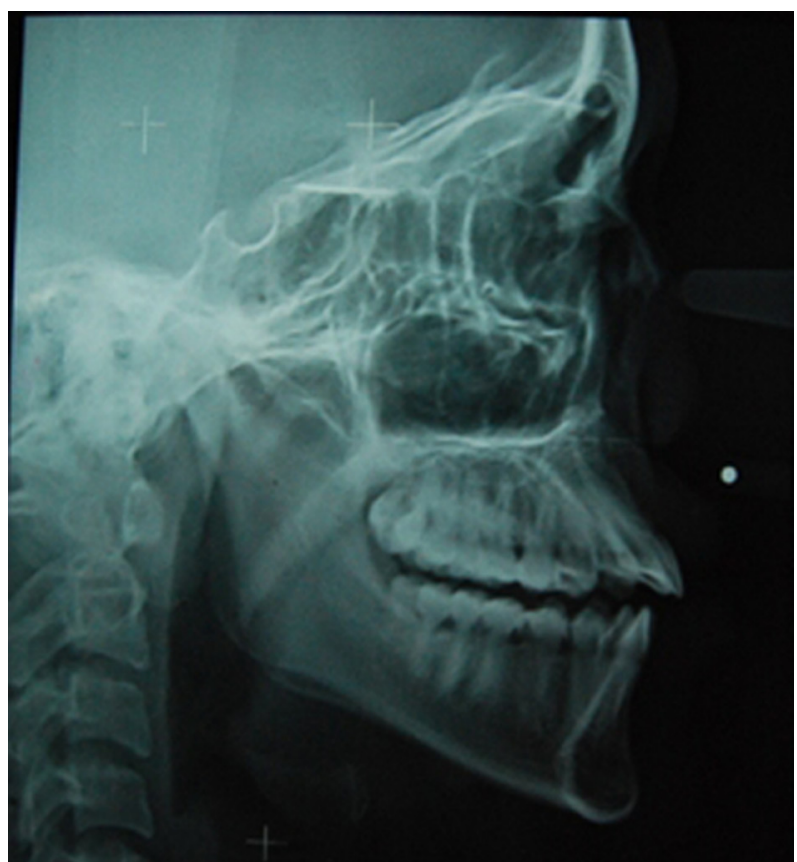

Figure 4 Lateral cephalogram.

formation normally takes place during the third month of pregnancy. ${ }^{9} 10$ Males and females are equally affected by Binder's syndrome.

Beside hypoplasia of the nose, patients may present bilateral loss of hearing and mental retardation (although there is no proof that Binder's syndrome is associated with lower intelligence). ${ }^{11}$ The majority of cases are isolated, but there are some reports of family recurrence of the syndrome (among siblings or parents and children); a positive family history was reported in $36 \%$ of the subjects of one study. ${ }^{12}{ }^{13}$ This suggests that the inheritance pattern is either autosomal recessive with reduced penetrance or multifactorial. ${ }^{9} 11-13$ There are reports that Binder's syndrome has a direct association with vitamin $\mathrm{K}$ deficiency. ${ }^{9}$ ${ }^{14}$ In some cases, other congenital diseases and abnormalities (such as Down's syndrome, autonomic neuropathy and strabismus) are observed. ${ }^{11}$ According to Nedev, 5\% of patients are found to present hearing loss and the same number of patients present congenital heart diseases. ${ }^{9}$

The nasolabial angle, measured between the tip of the nose and upper lip, is acute. According to Holmstroem et al., in Binder's syndrome it has a value of $76^{\circ}-88^{\circ}$ instead of the normal $103^{\circ}-117^{\circ}$ (according to Segner and Hasund's cephalometric analysis). The acute nasolabial angle is mainly a result of the convexity of the upper lip, a deep fold or fossa between the nose and the upper lip and a flat philtrum. ${ }^{3}$ 9-11 15

Delaire et al. observed that most Binder's syndrome patients suffer from microdontia of the central upper incisors; a lack of lateral incisors has also been observed, but rarely. ${ }^{11} 16$

In addition to skeletal changes in the skull, about $44.2 \%$ of Binder's syndrome patients present irregularities in the cervical spine, which arise during those structures' development in the third month of pregnancy - the same period

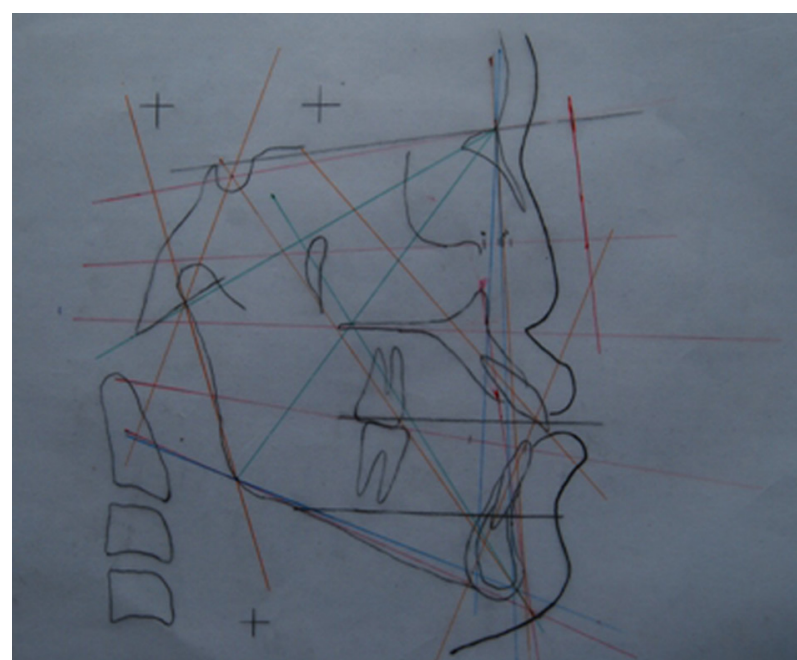

Figure 5 Cephalogram tracing.

as nose formation. Most frequently the $\mathrm{C} 1$ and $\mathrm{C} 2$ vertebrae are affected. Their hypoplastic arches may present abnormal patterns of ossification. ${ }^{8} 11$ The most frequent anomalies in vertebral structures are separate odontoid process, a short posterior arch, spina bifida occulta and blocked vertebrae. ${ }^{9}$

The management of these patients depends on the level of complexity because of variations in the midface discrepancy and the occlusal relationship. Some lesser-affected patients can be managed by using orthodontic camouflage alone, whereas others require multi-disciplinary input. The effects of posteroanterior traction, used to improve the facial aesthetics of an 11-year-old boy with maxillonasal dysplasia, were analysed; improvement in maxillary retrusion vis-à-vis the mandible only was accomplished, and the recorded advancement of the maxillary bones was slight $(0.6 \mathrm{~mm}) .{ }^{17}$

Osteotomy and grafts (bone or cartilage) are frequently used in the management of Binder syndrome. Grafts, when limited to the nasal sill, do not address the 'dish face' deformity characteristic of the syndrome. LeFort II osteotomy, although correcting the midface deficiency, can overcorrect the occlusal relationship if good dental camouflage has occurred, making a LeFort I osteotomy or orthodontic therapy necessary. It has been suggested that mild cases of Binder syndrome, without severe malocclusion, can be managed by using a cartilage graft around the nostril sill, dorsum, and the pyriform aperture, correcting the paranasal and infraorbital deformity without osteotomy. ${ }^{18}$ In more severe cases, however, a LeFort II osteotomy can correct the midface deficiency and the class III occlusion seen in $15 \%$ of patients with Binder syndrome, but it does not always fully address the nasal flatness. Twenty-seven patients with maxillonasal dysplasia of various degrees were examined on both short- and long-term bases. ${ }^{19}$ For some patients, surgical treatment began at age 3 , but others were treated as teenagers or young adults. The overall goals were to augment the skeletal deficiencies of the midface and begin the soft-tissue expansion process as early as possible. 


\section{BMJ Case Reports}

\section{Learning points}

Binder's syndrome is a rare congenital malformation that mainly affects facial features.

- Ultrasound screening and non-invasive genetic tests are performed to look for congenital anomalies as well as assessment of gestational age.

- The timing and types of procedures involved in the treatment of patients with maxillonasal dysplasia depend on the severity of the malformation and are planned individually.

- The optimum care of these patients requires an interdisciplinary approach; therefore all patients should be subjected to a thorough treatment planning in collaboration between orthodontists and oral and maxillofacial surgeons and/or plastic surgeon.

\section{Competing interests None.}

Patient consent Obtained.

\section{REFERENCES}

1. Zuckerkandl E. Fossae praenasales: normale und pathologische. Anat Nasenhohle 1882;1:48.

2. Noyes FB. Case report. Angle Orthod 1939;9:160.

3. von Binder KH. Dysostosis maxillo-nasalis, ein arhinencephaler Missbildungskomplex. Deutsche Zahnaerztl Z 1962;17:438.

4. Munro IR, Sinclair WJ, Rudd NL. Maxillonasal dysplasia (Binder's syndrome). Plast Reconstr Surg 1979;63:657-63.

5. Posnick JC, Tompson B. Binder syndrome: staging of reconstruction and skeletal stability and relapse patterns after LeFort I osteotomy using miniplate fixation. Plast Reconstr Surg 1997:99:961-73.
6. Holmström H. Clinical and pathologic features of maxillonasal dysplasia (Binder's syndrome): significance of the prenasal fossa on etiology. Plast Reconstr Surg 1986;78:559-67.

7. Rival JM, Gherga-Negrea A, Mainard R, et al. Dysostose maxillo-nasale de Binder. J Genet Hum 1974;22:263.

8. Olow-Nordenram M, Valentin J. An etiologic study of maxillonasal dysplasia-Binder's syndrome. Scand J Dent Res 1988;96:69-74.

9. Nedev PK. The Binder syndrome: review of the literature and case report. Int J Pediatr Otorhinolaryngol 2008;72:1573-6.

10. Holmström $\mathbf{H}$, Gewalli F. Long-term behavior of three different grafts in nasomaxillary reconstruction of binder syndrome: an analysis by digitalized measurements. Plast Reconstr Surg 2008;122:1524-34.

11. Quarrell OW, Koch M, Hughes HE. Maxillonasal dysplasia (Binder's syndrome). J Med Genet 1990;27:384-7.

12. Olow-Nordenram M, Valentin J. An etiologic study of maxillonasal dysplasia-Binder's syndrome. Scand J Dent Res 1988;96:69-74.

13. Olow-Nordenram MA, Rådberg CT. Maxillo-nasal dysplasia (Binder syndrome) and associated malformations of the cervical spine. Acta Radiol Diagn (Stockh) 1984;25:353-60.

14. Howe AM, Webster WS, Lipson AH, et al. Binder's syndrome due to prenatal vitamin K deficiency: a theory of pathogenesis. Aust Dent J 1992;37:453-60.

15. Dyer FM, Willmot DR. Maxillo-nasal dysplasia, Binder's syndrome: review of the literature and case report. J Orthod 2002;29:15-21.

16. Levaillant JM, Moeglin D, Zouiten K, et al. Binder phenotype: clinical and etiological heterogeneity of the so-called Binder maxillonasal dysplasia in prenatally diagnosed cases, and review of the literature. Prenat Diagn 2009;29:140-50.

17. Rune B, Sarnäs KV, Selvik G, et al. Posteroanterior traction in maxillonasal dysplasia (Binder syndrome). A roentgen stereometric study with the aid of metallic implants. Am J Orthod 1982;81:65-70.

18. Watanabe T, Matsuo K. Augmentation with cartilage grafts around the pyriform aperture to improve the midface and profile in binder's syndrome. Ann Plast Surg 1996;36:206-11.

19. Monasterio FO, Molina F, McClintock JS. Nasal correction in Binder's syndrome: the evolution of a treatment plan. Aesthetic Plast Surg 1997;21:299-308.

This pdf has been created automatically from the final edited text and images.

Copyright 2011 BMJ Publishing Group. All rights reserved. For permission to reuse any of this content visit http://group.bmj.com/group/rights-licensing/permissions.

BMJ Case Report Fellows may re-use this article for personal use and teaching without any further permission.

Please cite this article as follows (you will need to access the article online to obtain the date of publication).

Jain U, Thakur G, Kallury A. Binder's syndrome. BMJ Case Reports 2011;10.1136/bcr.08.2011.4665, date of publication

Become a Fellow of BMJ Case Reports today and you can:

- Submit as many cases as you like

- Enjoy fast sympathetic peer review and rapid publication of accepted articles

- Access all the published articles

- Re-use any of the published material for personal use and teaching without further permission

For information on Institutional Fellowships contact consortiasales@bmjgroup.com

Visit casereports.bmj.com for more articles like this and to become a Fellow 